\title{
Brief analysis on the teaching reform of PLC in Higher Vocational Education
}

\author{
Feng Xiaoling \\ (Liaoning Petrochemical Vocational College of Technology, Jinzhou, Liaoning, 121001)
}

Keywords: PLC course; teaching; reform strategy

\begin{abstract}
PLC course is a practical and comprehensive professional course in electrical engineering, mechatronics and automation, and other professional students will be exposed to the relevant knowledge and theory of PLC as well. At present, in the PLC curriculum teaching of domestic vocational colleges, because of the influence of various subjective and objective factors, the teaching effect and quality is difficult to be effectively improved. Therefore, in the future of the PLC curriculum teaching, we must take effective reform strategy to promote the continuous improvement of the level of PLC curriculum.
\end{abstract}

\section{Introduction}

For a long time, the mainstream of Higher Vocational Education in our country has been the academic education, students pay more attention to the study of theoretical knowledge, and only pursue academic credentials, but often pay less attention to vocational skills. As the mode of talent training is old, it does not reflect the characteristics of the application of personnel training, and thus out of the market demand. With the development of the market economy, the higher vocational education which is based on the degree of education has become increasingly unable to meet the needs of the society, the students cannot adapt to the actual needs of the enterprise after graduate.

In the face of such teaching object, if still use the traditional teaching methods, the effect is obviously unsatisfactory. Therefore, reforming the traditional teaching mode, effectively strengthen the students' skills training, so that students have more practical and useful technology, laying a good foundation for students to work and better align with the enterprise in the future, is the core of the PLC curriculum reform.

Enterprises need more and more high quality professional personnel, vocational colleges is the main place to transport personnel for enterprises, higher technology applied talents is trained for production, management, service, it is the school organization which is closest to enterprises. Currently, the higher vocational colleges in the country is under teaching reform. In the teaching reform of PLC curriculum in higher vocational colleges, teachers should consider the influence factors of various aspects, and further stimulate students' interest in this course to guide them to actively participate in the classroom teaching, so as to achieve significant improvement of the teaching efficiency and quality.

The teaching reform is the center of the sustainable development of education, and only through unremitting exploration and reform, using advanced methods and ideas, combining with national conditions and school conditions, a new way of teaching reform with the characteristics of higher vocational colleges can be developed.

\section{2. basis for the reform of PLC Curriculum teaching}

\subsection{PLC course teaching status}

At present, most of the PLC curriculum in Vocational Colleges in our country still follow the traditional teaching mode, which is mainly in the teaching mode that teacher writes on the blackboard, and the students are passively taking in the knowledge. Due to the general foundation of vocational colleges students is poor, many profound theoretical knowledge is difficult for students to understand, students generally feel "the theory of professional technology" is difficult to 
learn and easy to forget and rote learning to cope with the examination, resulting in "high scores and low abilities" phenomenon, which is very adverse for training high-quality applied talents.

From the PLC curriculum teaching situation, students in the classroom, although have a more solid theoretical knowledge, but cannot be combined with practice, so in the PLC curriculum teaching, the lack of combination of textbook knowledge and practice, leading to students' creative thinking control severely restricted, cannot train students to form a thinking mode with its own characteristics and problem-solving ideas. Even when the students enter the skill practice teaching, often limited to mimic operation training, and unable to comprehend by analogy and form skill system. Therefore, students generally have the weak ability to analyze problems and solve problems.

Through several years of teaching practice, there are some problems found in the current PLC curriculum, mainly including: curriculum is not fully consistent with the needs of the post, the students after graduation, the employer should arrange on-the-job training for students; the original assessment standards pay attention to the theory and results, and the students ability training and process assessment are ignored, the comprehensive ability of graduates is not outstanding.

Therefore, in the course of teaching, there are both theory and practice, both the working principle and programming method, both the typical unit program and complex practical case, which decides that we should take different teaching methods according to different teaching contents and characteristics.

2.2 status of $P L C$

PLC course is a practical and comprehensive course in electrical engineering, mechatronics and automation field. The teaching objective is to make the students master the basic principle of PLC and its application in the automatic control system. The students is trained to use PLC instead of the traditional relay control system, maintain and manage automation product line as the basic skills, and lay a good foundation for the application and development of modern soft production line control technology. As a result, the PLC course is a comprehensive and practical professional course.

\section{3. specific strategies for the teaching reform of PLC}

For students in higher vocational colleges, they not only need a strong professional skills, but also need the courage to innovate, so as to meet the needs of the community for new talent.

For higher vocational college teachers, in the PLC curriculum teaching, teachers should actively study advanced educational ideas, and combined with the actual situation of teaching, and constantly update the current educational ideas. Especially in classroom teaching, teachers should change the teaching mode from "the teacher as the center" to "take the student as the center", to give students more space for self-expression, and stimulate the students' creative potential and initiative, so as to promote the continuous improvement of innovation ability of students.

The most prominent feature of higher vocational education is to strengthen students' ability to apply technology, and pay attention to the cultivation of students' manipulative ability. Therefore, breaking the traditional subject curriculum model, which has the main characteristic of knowledge-transference, changed into the work task as the center and organize course content, and let the students learn to complete corresponding work task in the process of completing the specific project, and to construct the relevant control theory knowledge, develop vocational ability.

\section{1 reform of teaching mode}

With the full implementation of quality education and the new curriculum concept, it also puts forward higher standards and requirements for the teaching of PLC course. In order to achieve the best teaching effect, the traditional teaching mode is broken, and the old teaching mode based on theory is transformed into teaching integration of theory and practice, and the teaching method of "task driven" will be suitable for higher vocational education.

Task driven teaching method is a teaching method based on Constructivism Teaching theory. The so-called "task driven" is to let students under the driver of a typical PLC program design "task", to expand teaching activities, and guide students from simple to complex, from easy to difficult, step 
by step to complete a series of tasks, so as to build their own knowledge and skills. The tasks not only contains the knowledge and skills students should master, but also contains the ability training students need to get. In the process of completing the task, develop the students' ability to analyze and solve problems.

\section{2 reform of teaching content}

The content of vocational education curriculum must be based on the professional activities. Examples of the course should focus on the implementation of the professional ability object, as far as possible based on the professional post and the actual work flow to reform the content and order of the course.

PLC course covers a wide range of knowledge, teaching difficulty is large, in the design process of course, need to carry out enterprise investigation, based on the needs of professional post and the principle of "necessary, sufficient, applicable", dilute the pure theoretical teaching content in this course related with other courses, and choose teaching materials reasonably.

\section{3 reasonable reform of teaching materials}

In the teaching of PLC course, the teaching material of this stage has been adjusted several times, but there are still a lot of chapters and contents which are not suitable to the practical teaching. As the theoretical foundation of vocational college students is weak, it is difficult to form the learning interest in the teaching material, which is boring and monotonous. Therefore, in the teaching of PLC course, teachers should be based on the summary and accumulation of teaching experience, reasonable reform teaching materials, grasp the focus of teaching.

\section{4 strengthen practical teaching, enhance students' manipulative ability}

At the present stage of PLC teaching in the domestic vocational colleges, because the school training room construction lags behind, the lack of school enterprise cooperation and other reasons, the proportion of theoretical teaching is significantly higher than the practical teaching. Moreover, most of the current practice teaching is based on the experiment, students are grouped for experiment after the theory course. The experimental contents, methods of operation are explained by the teacher, then the students follow the prescribed order to complete the operation. This experiment, students just to verify the results, neither pleasure nor innovation. More theoretical study will make students feel bored and get weariness of the entire course, it can be said that, the experiment process is the boring process of no purpose.

In order to further strengthen the practice teaching of PLC course, teachers should realize the importance of practicing teaching, and the positive influence on the students' learning interest and enhancing students' ability of operation; Secondly, in the teaching process of the PLC curriculum, teachers should fully mobilize the enthusiasm of students to participate in the practice, and encourage students to dare to show themselves in front of the students; Finally, in practice teaching, teachers should guide students to break the shackles of the book knowledge, pay attention to the organic connection with production in practice, and then form a strong practical ability.

In the training program, the work should be started closely around the job content, in order to adapt to the training mode of combining work and study, to increase the students' manipulative chance and strengthen students' professional ability. At the same time, in the functional division of the special laboratory, should be based on teaching mode in favor of the implementation of the task driven and project oriented.

\section{5 update teaching evaluation mechanism}

In the teaching of PLC course, the importance of updating teaching evaluation system cannot to be ignored, it is the key link to promote students' comprehensive grow up and development. In the past PLC course teaching evaluation, teachers' evaluation of students' performance is generally lack of objectivity, rationality and fairness, which leads to the students' learning enthusiasm, self-esteem are damaged, it is not consistent with the concept of modern education.

In the future PLC curriculum teaching evaluation, teachers should insist on the basic principle of respecting students' personality development, breaking the traditional evaluation method, realizing the change from "valuing result evaluation" to "valuing process evaluation", that is not to evaluate 
student only by simple test scores, but pay more attention to students' self-study ability, restudy ability, creative thinking ability, the ability of independent thinking, analysis and solving problems.

In the course of teaching, the students' learning effect is assessed and evaluated, in which the assessment and evaluation methods to assess the effect of teaching is also an important influence. Such as the current examination and selection system prone to the phenomenon of high scores and low abilities, especially in the vocational education, there is the need to reform the phenomenon that exam papers determined the results of the study, and should be more focused on the formation of professional skills and grasp of skills. In the course based on the work process, should pay more attention to the assessment of students in the work process of the dominant and recessive knowledge. Therefore, we need to establish a scientific evaluation mechanism, fully respect the students' personality, interest, ability, the assessment should be diversified, and the assessment criteria should be refined and clear.

3.6 establish mutually beneficial cooperative relations with the enterprise, form the long-term training base

To establish mutually beneficial cooperative relations with enterprises, the school provides venues and related resources, enterprise invests machinery and equipment, instrumentation and production tools, to build enterprise economic entities and achieve resource sharing. In this way, the enterprise can not only directly into the social production and management, students can also go the actual production post for teaching activities easily, use advanced production tools and equipment directly, contact the industry's new technology, it is more easy to achieve work and learning alternate, to achieve "seamless joint" of "students" and "workers".

In cooperation with enterprises to build off campus practice base, to guide enterprises to actively absorb students PLC professional training and post practice; improve the cooperation mechanism, so that students can get good guidance in the enterprise practice period, and strengthen the teaching mode of school enterprise joint training, combining of the engineering and learning. The school enterprise cooperation network information platform is used, according to the enterprise production process to adjust the execution time of the practice flexibly, teaching practice can better follow the production process, and better realize the combination of working and studying.

\section{7 teacher training}

Teachers may have some defects in the knowledge structure, especially the work experience and practical skills of enterprises cannot be competent for the needs of the reform of the work and study, through the teacher training and the enterprise practice, teachers can participate in the production practice, through the efforts to become a "double teacher" teacher. In order to improve the quality of teaching, we need to strengthen the construction of teachers.

At present, the talent training mode of "combination of working and learning, enterprise and school cooperation" can not only strengthen the cultivation of young teachers, introduce outstanding talents, but also can form the teachers' troop to meet the needs of reform. On the one hand, hire the part-time teacher from the enterprise to release the contradiction between the structure of professional teachers and professional construction structure, and the extension of "double qualified teachers" is broaden, the professional personnel hired from the enterprise is regarded as the important measures of "double qualification" team. On the other hand, the establishment of the combination of professional teachers and enterprise training teachers, is conducive to the formation of the "double" quality teachers.

\section{Conclusions}

The teaching purpose of PLC courses and other engineering courses, is to transport professional personnel of professional foundation knowledge and certain technical experience to society. Vocational schools should change the educational concept from imparting knowledge to the cultivation of students' ability, like innovative ability, comprehensive ability, practical ability and cooperative ability. By allowing students to participate in the actual work of enterprise, students 
understand the requirements for skills and quality of the staff, and lay a good foundation for the future into the community.

In short, PLC is a practical and technological course combining theory and practice. It starts from the theory, focuses on teaching practice, uses market demand and orientation as the breakthrough point, through the combination of experiments and practice, and masters the practical training of student, stimulates students' interest in learning, and strengthens the manipulative ability, trains the students to analyze and solve problems.

\section{References}

[1] Jin Sha. PLC application technology. China Electric Power Press. 2010. 2

[2] Liu Yumei, Zhang Liwen. Process control technology. Chemical Industry Press. 2009

[3] Liu Meijun. Application and maintenance of SIEMENS S7 series PLC. 2008

[4] Ding Guoming. The exploration and practice of the teaching mode of PLC integration module [J]. Scientific and technological information, 2009.9.

[5] Hu Jian. SIEMENS S7-300PLC application tutorial. China Machine Press, 2012.12.

[6] S7-300 manual. German SIEMENS Automation Co., Ltd.

[7] Xu Jun. Teaching reform practice of "PLC technology and application" [J]. Mechanical vocational education, 2009.5

[8] Sun Rong, Wang Chenye, Zhang Lanyong. The practice and application of Siemens S7-300\400PLC. China Machine Press, 2013.

[9] Yuan Qingping. The teaching reform of the electrical control and PLC technology, [J]. Journal of Tongling Polytechnic, 2009

[10] Wang Jian, Shi Yonggui, Li Lijun. PLC practical technology. China Machine Press, 2012. 